\title{
The Current Stream and Prospect of Glycoscience Application -Therapeutic Antibodies-
}

\author{
糖鎖に関わる応用研究の潮流と展開一抗体医薬一
}

\author{
Satoh, Mitsuo ${ }^{1 *}$; Shitara, Kenya ${ }^{1}$; and Hanai, Nobuo ${ }^{2}$ \\ ${ }^{1}$ Tokyo Research Laboratories, Kyowa Hakko Kogyo Co., Ltd., 3-6-6 Asahi-machi, Machida-shi, Tokyo 194-8533, Japan \\ ${ }^{2}$ BioWa, Inc., 212 Carnegie Center Suite 101, Princeton NJ, 08540, USA \\ ${ }^{*}$ Corresponding author: Satoh, Mitsuo \\ FAX: 81-42-726-8330, E-mail: msatoh@kyowa.co.jp
}

Key Words: therapeutic antibodies, Fc reigon, $N$-linked oligosaccharide, FUT8 ( $\alpha$-1,6-fucosyltransferase), ADCC (antibody-dependent cellular cytotoxicity)

\begin{abstract}
Many therapeutic antibodies have been approved since the late 1990s, and these agents represent a major new class of drugs. However, there still remains room for improvement in the clinical effect and cost of therapeutic antibodies licensed on the market. Most therapeutic antibodies, which currently have been developed as medical agents, are human IgG1 whose molecular weight is approximately $150 \mathrm{kDa}$. Human IgG1 is a glycoprotein bearing two $\mathrm{N}$-linked oligosaccharides bound to the antibody constant region $(\mathrm{Fc})$, and exercises its effector functions of antibody-dependent cellular cytotoxicity (ADCC) and complement-dependent cytotoxicity (CDC) through the interaction of the $\mathrm{Fc}$ with either lymphocyte receptors (Fc $\gamma \mathrm{Rs})$ or complements. Recently, therapeutic antibodies have been shown to improve overall survival as well as time to disease progression in a variety of human malignancies such as breast, colon and haematological cancers (1-4), and genetic analysis of FcyR polymorphisms of cancer patients has demonstrated that ADCC is a major anti-neoplasm mechanism responsible for the clinical efficacy of antiCD20 antibody Rituxan ${ }^{\mathrm{R}}$ (rituximab) and anti-Her2 antibody Herceptin $^{\mathrm{R}}$ (trastuzumab) (5-9). Thus, there are currently numerous efforts to improve ADCC of therapeutic antibodies. We have found that the removal of fucose residues from the biantennary complex-type oligosaccharides attached to the Fc dramatically enhances the ADCC of the IgG due to improved Fc $\gamma$ RIIIIa binding (10-17), and have developed the technology, designated as Potelligent ${ }^{\mathrm{TM}}$, to control the fucosylation of therapeutic antibodies $(18,19)$. Application of this technology has now started for the development of the next generation of more effective therapeutic antibodies.
\end{abstract}

\section{要 約}

1990 年後半から抗体医薬品が次々と認可され、これら認 可された多くの抗体医薬は新しい医療として定着しつつある。 しかし、現行の抗体医薬の臨床効果は必ずしも充分なもので はなく、また、投与量が多いため薬剤費が高いといった課題 が残されている。医薬として開発されている抗体のほとんど は分子量約 $150 \mathrm{kDa}$ のヒト IgG1 であり、その $\mathrm{Fc}$ 領域に 2 本の $N$-グリコシド結合複合型糖鎖が結合する糖タンパク質である。 $\mathrm{Fc}$ 領域は Fc 受容体や補体などが結合する領域であり、この部 分を通じて抗体依存性細胞傷害活性 (antibody-dependent cellular cytotoxicity; ADCC) や補体依存性細胞傷害活性 (complementdependent cytotoxicity; CDC) といったエフェクター活性が発揮 される。最近の抗体医薬の臨床成績では、乳癌、大腸癌、血 液癌といった多くのヒト悪性腫瘍において、延命や病態悪化 に至るまでの期間延長といった効果が観察されている(1-4)。 また、癌患者 $\mathrm{Fc}$ 受容体の多型解析から、非ホジキンリンパ腫 治療薬抗 CD20 抗体 Rituxan ${ }^{\mathrm{R}}$ (リッキシマブ) や乳癌治療薬抗 Her2 抗体 Herceptin ${ }^{\mathrm{R}}$ (トラスツズマブ)の主たる抗腫瘍メカニ ズムの一つは ADCC 活性であることが明らかにされ(5-9)、医 薬開発に応用可能な ADCC 活性増強技術の開発が次世代抗体 技術として注目されている。我々は、抗体の Fc 領域に結合し ているN-グリコシド結合複合型糖鎖からフコースを除去する ことで Fc 受容体 IIIa に対する親和性を向上させ ADCC 活性を 大幅に高められることを見出し(10-17)、このフコース修飾を 制御する技術を開発した $(18 、 19)$ 。現在、次世代抗体医薬の開 発のため、Potelligent ${ }^{\mathrm{TM}}$ と名付けたこの技術の応用を精力的に 開始している。

\section{A. Introduction}

Progress has been made in antibody engineering technology in the last decade, which has enabled the

\section{A. はじめに}

近年の抗体工学の進歩により、ヒトに対する抗原性が低 く、臨床応用可能な遺伝子組換え抗体の作製が可能となった。 
production of recombinant monoclonal therapeutic antibodies such as humanized antibody and human antibody, both of which are of sufficiently low immunogenicity for clinical applications. Mouse/human chimeric antibody and complementarity determining region (CDR)-grafted antibody have been generated as humanized antibodies by gene engineering technology (20-24), and fully-humanized antibodies have been generated from either transgenic mice capable of producing human antibody or phage libraries of human immunoglobulin (25-31). Human genome has been sequenced and almost all information of protein antigens is now available for generation of molecular-target base medicines, which is stimulating strong competition in the development of therapeutic antibodies (32). Numerous trials using therapeutic antibodies are currently underway, including 100 clinical and more than 300 pre-clinical studies. Thus, 17 types of recombinant monoclonal therapeutic antibodies have already been approved in the USA, and these agents represent a major new class of drugs (Table I). Each of the world sales of anti-CD20 IgG1 Rituxan ${ }^{\mathrm{R}}$ (rituximab) for non Hodgkin's lymphoma and of anti-TNF- $\alpha$ IgG1 Remicade ${ }^{R}$ (infliximab) for chronic rheumatoid arthritis and Crohn's disease reached approximately 2 billion dollars in 2004. In the near future, rituximab will be administered to far more patients than currently treated patients as it has been reported that clinical efficacy of ritiximab for chronic rheumatoid arthritis was observed in phase III clinical study. Moreover, it becomes the most conspicuous topic of therapeutic antibodies that anti-VEGF IgG1 Avastin $^{\mathrm{R}}$ (bevacizumab) licensed in late 2004 has demonstrated statistically significant improvement in overall survival of patients with metastatic cancers of
具体的には、マウス/ヒト型キメラ抗体やヒト型相補性決定 領域 (complementarity determining region; CDR) 移植抗体などの ヒト化抗体作製技術の開発や(20-24)、ヒト抗体産生トランス ジェニックマウスやファージライブラリーを利用した完全ヒ 卜抗体作製技術の開発が(25-31)、モノクローナル抗体治療を 医薬として可能ならしめたと言える。抗原となるヒトのゲノ ム情報が完全に解読された今日、抗体医薬は分子標的医薬の 代表として嬂烈な競争時代に入っている(32)。現在、世界で は、100を超える臨床試験と 300 を超える前臨床試験が行われ ていると言われている。米国では、既に、17 種類の抗体が医 薬品として承認販売されており、抗体は新しい医療分野を開 拓しつつある(表 I)。これら認可された抗体医薬の中でも、癌 領域では非ホジキンリンパ腫適応の抗 CD20 キメラ抗体 Ritux$\mathrm{an}^{\mathrm{R}}$ (リッキシマブ) が、炎症領域では慢性関節リュウマチ及 びクローン病適応の抗 TNF- $\alpha$ キメラ抗体 Remicade ${ }^{\mathrm{R}}$ (インフ リキシマブ)が、それぞれ、およそ2000 億円という売り上げ を 2004 年度に記録した。リツキシマブは、さらに、慢性関節 リュウマチ適応への適応拡大を狙った第 3 相試験においても 有望な治療効果が報告されており、今後より多くの患者さん の治療に用いられる可能性がある。また、2004 年下期に認可 された抗 VEGF ヒト化抗体 Avastin $^{R}$ (ベバシズマブ)は、それ まで多くの薬剤が試されたが有効な治療効果が得られなかっ た大腸癌に㧈いて、化学療法との併用で有意な延命効果を示 し話題となった(33-35)。ベバシズマブは、米国に㧍いて、発

Table I. Recombinant therapeutic antibodies on the market USA.

\begin{tabular}{|c|c|c|c|c|c|}
\hline Trade & Company & Type & Antigen & Indication & Approval Date \\
\hline Reopro $^{\mathrm{R}}$ & Centocor/Lilly & Chimera & gpIIb/IIIa & Thrombosis & $12 / 24 / 1994$ \\
\hline Rituxan $^{\mathrm{R}}$ & IDEC/Genentech/Roche & Chimera & CD20 & NHL & $11 / 26 / 1997$ \\
\hline Zenepax $^{\mathrm{R}}$ & Roche & Humanized & IL-2R & Transplantation & $12 / 10 / 1997$ \\
\hline Simulect ${ }^{R}$ & Novartis & Humanized & $\mathrm{IL}-2 \mathrm{R}$ & Transplantation & 05/12/1998 \\
\hline Synagis $^{\mathrm{R}}$ & MedImmune/Abott & Humanized & RSV & RSV Infection & 06/19/1998 \\
\hline Remicade $^{R}$ & Centocor/J\&J & Chimera & TNF- $\alpha$ & RA, Crohn's & 08/24/1998 \\
\hline Herceptin $^{\mathrm{R}}$ & Genentech/Roche & Humanized & Her2 & Breast Cancer & 09/25/1998 \\
\hline Mylotarg ${ }^{\mathrm{R}}$ & Cellutech/AHP & Drug-conjugate & CD33 & AML & $05 / 17 / 2000$ \\
\hline Campath $^{\mathrm{R}}$ & ILEX/Schering & Humanized & CD52 & B-CLL & $05 / 05 / 2001$ \\
\hline Zevalin $^{\mathrm{R}}$ & IDEC/Schering & ${ }^{90} \mathrm{Y}$-conjugate & CD20 & NHL & $02 / 19 / 2002$ \\
\hline Humira $^{\mathrm{R}}$ & Abott/CAT & Fully human & $\mathrm{TNF}-\alpha$ & RA & $12 / 31 / 2002$ \\
\hline Xolairr $^{R}$ & Genentech/Novartis/Tanox & Humanized & $\operatorname{IgE}$ & Allergic asthma & $06 / 20 / 2003$ \\
\hline Bexxar $^{R}$ & Corixa/SKB & ${ }^{131}$ I-conjugate & $\mathrm{CD} 20$ & NHL & $06 / 27 / 2003$ \\
\hline Raptiva $^{\mathrm{R}}$ & Genentech/Xoma & Humanized & LFA-1 & Psoriasis & $10 / 27 / 2003$ \\
\hline Erbitux $^{\mathrm{R}}$ & ImClone/BMS/Merck & Chimeric & EGFR & Colon Cancer & $02 / 12 / 2004$ \\
\hline Avastin $^{\mathrm{R}}$ & Genentech & Humanized & VEGF & Colon Cancer & $02 / 26 / 2004$ \\
\hline Tysabri $^{\mathrm{R}}$ & Biogen-IDEC/Elan & Humanized & Integrin $\alpha 4 \beta 1$ & MS & $12 / 23 / 2004$ \\
\hline
\end{tabular}

RSV: respiratory syncytial virus, NHL: non-Hodgkin lymphoma, AML: acute myeloid leukemia, B-CLL: B-cell chronic lymphocytic leukemia, RA: rheumatoid arthritis, MS: Multiple sclerosis. 
the colorectum in combination with standard chemotherapy regimens (33-35). The first year sales of bevacizumab in the USA, indeed, recorded 0.5 billion dollars. The clinical efficacy of bevacizumab for both breast and lung cancers in phase III study has been also reported at the American Society of Clinical Oncology (ASCO) held in 2005. Thus, it is thought that the indication of therapeutic antibodies will be expanded, and we have to face a severe problem of the expensive cost of therapeutic antibodies.

\section{B. The Need for Next-generation Therapeutic Antibodies}

Although various antibody therapies are currently recognized as novel medicines that confer great benefits to patients, these agents also bring up an issue referred to as "economical toxicity". The drug costs alone of treatment with anti-tumor therapeutic antibodies of rituximab, trastuzumab or bevacizumab can amount to over 10-20 thousand dollars due to a significant amount of drug needs for clinical efficacy. The world sale of currently licensed recombinant therapeutic antibodies in 2005 is estimated to exceed 10 billion dollars. As mentioned above, the indication of therapeutic antibodies will be further expanded in the near future. This economic situation is not viable, and is at risk of collapse. Moreover, there still remains the need to improve the efficacy of many antibody therapeutics such that they can be used to achieve not only remission, but complete recovery from disease; many of the currently approved antibody therapies remain unable to induce more than remission. Therefore, the development of the next-generation therapeutic antibodies with enhanced clinical efficacy is expected.

\section{Physiological Mechanism of Therapeutic Antibodies}

Physiological action of therapeutic antibodies is based on two mechanisms of antibody; the efficacy of therapeutic antibody is the result of target antigen specificity and biological activities referred to as antibody effector functions, and which are activated by the formation of immune complexes shown in Fig. 1. We can classify therapeutic antibodies into two types, one of which is therapeutic antibodies functioning as neutralizing agents of the molecular target causative of aggravated disease. Both infliximab and bevacizumab are known as typical such neutralizing therapeutic antibodies. Neutralization of the specific antigen function is mediated by the antigen-binding region of the antibody (Fab). Therapeutic antibodies can also mediate the effector functions of antibody-dependent cellular cytotoxicity (ADCC), complement-dependent cytotoxicity (CDC), and the direct induction of apoptosis via the constant region of the antibody $(\mathrm{Fc})(36-39)$. Rituximab and antiHer2 antibody Herceptin ${ }^{\mathrm{R}}$ (trastuzumab) are known as typical therapeutic antibodies showing their clinical efficacy through
売初年度 600 億円を超える売り上げを記録している。さらに、 非小細胞肺癌、乳癌に対する第 3 相試験でもべバシズマブに よる良好な治療結果が 2005 年の米国臨床癌学会 (American Society of Clinical Oncology; ASCO)で報告されており、今後の開 発動向が非常に注目されている。このように、抗体医薬が適 応される疾患はより広がるものと思われるが、一方で高い薬 剤費の問題が深刻さを増してきている。

\section{B. 次世代抗体医薬開発の必要性}

新たな医療として認知され始めた抗体医薬ではあるが、 多くの患者さんに恩恵をもたらすと同時に、“economical toxicity” と挪揄される新たな課題を我々に突きつけ始めた。リツキ シマブ、トラスッズマブ、あるいはベバシズマブといった抗 癌抗体医薬の薬剤費は、薬効発現のために多くの量の抗体投 与が必要となるため、100〜 200 万円と高額なものにならざる を得ない。現在認可されている遺伝子組み換え抗体医薬品の 2005 年の総売上は 1 兆円を超えると見積もられている。さら に、上述のごとく、抗体医薬の適応は近い将来より広がるで あろう。このままでは、医療保険制度の維持は難しく医療経 済の破綻は免れない。また、現行の抗体医薬において癌患者 さんの顕著な延命効果が報告されているものの、完治に向け て一層の治療効果の改善が求められている。このような背景 から、より治療効果の高い次世代抗体医薬の開発が求められ ている。

\section{C. 抗体医薬の薬効メカニズム}

抗体医薬の薬効メカニズムは抗体が有する $2 つ$ 生物活 性に基づいている。すなわち、標的抗原特異的な結合活性と エフェクター活性と呼ばれる抗体の生物活性によってその薬 効は発揮されており、これら活性の発現には図 1 に模式的に 示した抗原抗体複合体の形成が必要である。抗体医薬品は、

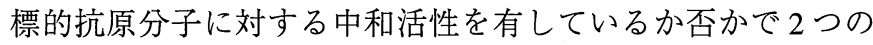
タイプに分類することができる。病態形成に重要な役割を 担っている標的分子に対する中和活性が薬効発現に必要な抗 体医薬としてはインフリキシマブやベバシズマブが代表的な 例として挙げられる。標的抗原分子の機能の中和は抗体の抗 原結合領域である $\mathrm{Fab}$ を敒発揮される。一方、抗体医薬 は Fc と呼ばれる抗体定常領域を介して、抗体依存性細胞傷害 活性 (antibody-dependent cellular cytotoxicity; ADCC) や補体依存 性細胞傷害活性 (complement-dependent cytotoxicity; CDC) ある いはアポトーシスの直接誘導といったエフェクター活性を発 揮することができる(36-39)。このエフェクター活性を利用し て薬効を発現する抗体医薬としてはリツキシマブや抗 Her2 抗 


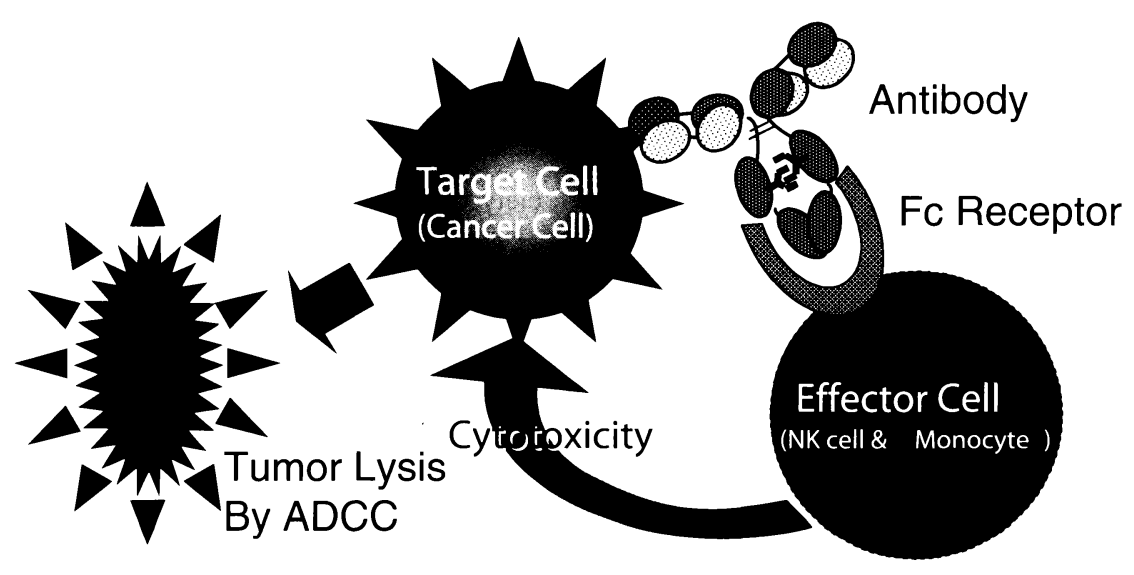

Fig. 1. Schematic drawing of ADCC. IgG-antibody-coated tumor cells are efficiently killed by monocytes or NK cells, which have $\mathrm{Fc}$ receptors able to bind to the $\mathrm{Fc}$ region of $\mathrm{IgG}$ molecules. The binding of the antibody-covered tumor cells to these $\mathrm{Fc}$ receptors activates the cytotoxic process ADCC.

the effector functions. There are currently numerous ongoing efforts mainly to improve the effector functions of therapeutic antibodies (40-42).

\section{Importance of ADCC on Clinical Efficacy of Therapeutic Antibodies}

ADCC, a lytic attack on antibody-targeted cells, is triggered upon the binding of lymphocyte receptors ( $\mathrm{Fc} \gamma \mathrm{Rs})$ on specialized killer cells of natural killer (NK) cells and macrophages to the antibody $\mathrm{Fc}$ region. Although the nature and importance of effector functions of ADCC, CDC, and the direct induction of apoptosis in influencing physiological activity of therapeutic antibodies have long been recognized, the most important function in terms of the clinical efficacy has remained a matter of debate. Among these functions, ADCC in particular is considered to be an important mechanism of clinically effective antibodies (43). Recently, therapeutic antibodies have been shown to improve overall survival as well as time to disease progression in a variety of human malignancies such as breast, colon and haematological cancers (1-4). Genetic analyses of Fc $\gamma \mathrm{R}$ polymorphisms, in the case of both non-Hodgkin's lymphoma and breast cancer patients, have clearly demonstrated that ADCC is one of the critical effector functions responsible for the clinical efficacy of these agents (5-9). A superior clinical response of patients with the FcyRIIIa allotype (FcyRIIIa-158Val), which has high affinity for rituximab, has been observed, in contrast to the results obtained from patients with the low-affinity allotype (FcyRIIIa-158Phe) (5-8). Breast cancer patients who responded to trastuzumab with complete or partial remission were found to have a higher capability to mediate in vitro ADCC when treated with trastuzumab than the non-responders (9). These facts have demonstrated the importance of ADCC in the development of antibody therapies that are clinically
体 Herceptin ${ }^{\mathrm{R}}$ (トラスッズマブ)が代表的な例として挙げられ る。現在、抗体医薬の薬効を高める研究としてエフェクター 活性を向上させる研究が盛んに行われている(40-42)。

\section{D. 抗体医薬の臨床効果における ADCC 活性の重要性}

ADCC 活性とは、標的細胞に結合した抗体が NK 細胞や マクロファージなどのエフェクター細胞上の Fc 受容体と結合 することで、抗体依存的に誘導される標的細胞傷害活性であ る。抗体医薬の薬効発現のメカニズムとして、ADCC 活性や CDC 活性あるいはアポトーシスの直接誘導といったエフェク ター活性の重要性が古くから指摘されているが、臨床上どの メカニズムが最も重要なのか明らかとなっていなかった。現 在では、これらメカニズムの中では、特に、ADCC 活性が重 要なメカニズムの一つであると考えられつつある(43)。最近 になり、多くの抗体医薬の臨床成績が明らかになるにつれ、 乳癌、大腸癌、血液癌といった多くのヒト悪性腫瘍において、 延命や病態悪化に至るまでの期間延長といった抗体医薬の臨 床効果が明確となってきた (1-4)。そして、非ホジキンリンパ 腫及び乳癌の癌患者さんの Fc 受容体多型解析が行われ、リツ キシマブ及びトラスツズマブいずれにおいても、その主たる 抗腫瘍メカニズムの一つは ADCC 活性であることが明らかに されてきている (5-9)。ヒトの Fc $\gamma$ 受容体 IIIaには、158 番目

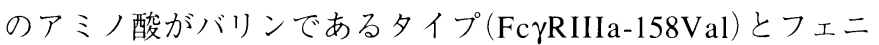
ルアラニンであるタイプ(Fc $\gamma$ RIIIa-158Phe) の遺伝子多型が存 在する。治療抗体リツキシマブに対して高い親和性を示す Fc 受容体 Fc $\gamma$ RIIIa-158Val を有する非ホジキンリンパ腫患者は、 低親和性を示す Fc 受容体 Fc $\gamma$ RIIIa-158Phe を有する患者に比 べてより優れた臨床効果を示した(5-8)。トラスツズマブによ る乳癌治療に扔いても、完全寛解あるいは部分寛解した患者 さんでは治療効果が観察されなかった患者に比べて、末梢血 をエフェクター細胞として用いたインビトロ ADCC 活性測定 において、トラスッズマブによる有意に高い活性が検出され ている $(9)$ 。これらの結果は、臨床的に効果のある抗体医薬を 
effective. ADCC enhancement technology applicable for clinical applications is expected to a key technology in the development of next-generation therapeutic antibodies with enhanced clinical efficacy.

\section{E. Defucosylated Antibodies as Next-generation Therapeutic Antibodies}

As the shortcomings of currently licensed therapeutic antibodies, especially for the treatment of cancer patients, is also recognized, there are numerous challenges to improve the efficacy of therapeutic antibodies. These challenges have included both the effector function enhancement of antibody and co-administration of adjuvants such as cytokines and CpG (44-47). Among these efforts, ADCC enhancement strategy is attracting recent attention as the importance of ADCC on clinical efficacy of therapeutic antibodies is widely recognized. There are two types of approach to enhance ADCC of therapeutic antibodies; both the introduction of point mutations into the $\mathrm{Fc}$ region of antibody $(48,49)$ and the modification of $N$-linked oligosaccharides attached to the Fc region of the antibody (50) are available. Therapeutic antibodies have two $N$-linked oligosaccharide chains bound to the $\mathrm{Fc}$ region as shown in Fig. 2. The oligosaccharides are of the complex biantennary type, composed of a mannosylchitobiose core structure with the presence or absence of core fucose, bisecting $N$-acetylglucosamine (GlcNAc), galactose, and terminal sialic acid, which gives rise to structural heterogeneity (51-53). Human IgG is primarily employed as therapeutic agent, and both human serum IgG and therapeutic antibodies are well known to be heavily fucosylated (54, 55). Human IgG has a unique oligosaccharide structure in which multiple, non-covalent interactions between the oligosaccharides and the protein portion of the $\mathrm{C}_{\mathrm{H}} 2$ domains results in reciprocal influences of each on the conformation of the other (56-58). Although the influence of the refined Fc oligosaccharide structures on ADCC of IgG has long
開発するには、ADCC 活性が重要であることを示唆している。 臨床応用可能で、かつ既存抗体の ADCC 活性を増強すること ができる技術の開発が臨床効果を高めた次世代抗体医薬の開 発の鍵を握ると言われる所以である。

\section{E. 次世代抗体医薬としてのフコース非修飾抗体}

現行の抗体医薬の課題が明らかになるにつれ、抗体医薬 の臨床効果を増強させる多くの試みが開始されている。これ ら試みの中には、抗体自身のエフェクター活性を増強させよ うとする試み以外にも、抗体医薬と併用してその効果を高め ようとするサイトカインや CpG を用いたアジュバント療法 開発といった試みも含まれている(44-47)。中でも、抗体自 身のエフェクター活性を増強させようとする試みは、抗体医 薬の臨床効果発現に ADCC 活性が重要であるという認識が 広まるにつれ、大変注目を集めるようになった。抗体医薬の

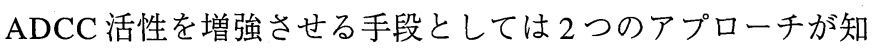
られている。その一つは、抗体の $\mathrm{Fc}$ 領域のアミノ酸配列を

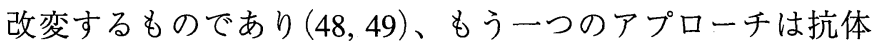
の Fc 領域に結合している糖鎖の構造を制御するものである (50)。図 2 に示すように、抗体は 2 つの $N$-グリコシド結合糖 鎖を $\mathrm{Fc}$ 領域に有している。この抗体の $N$ - グリコシド結合糖 鎖は、Mannosyl-chitobiose Core 構造を基本構造とする複合型 2 本鎖糖鎖であり、非還元末端側ではガラクトース、バイセ

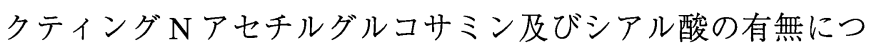
いて、還元末端ではフコースの有無について多様性が存在し ている(51-53)。抗体医薬はヒト IgG が用いられて開発されて おり、ヒト血中 $\mathrm{IgG}$ も抗体医薬もいずれも高度にフコース修 飾されていることが知られている $(54,55)$ 。ヒト IgGでは、糖 鎖部分と $\mathrm{C}_{\mathrm{H}} 2$ ドメインのタンパク質部分が非共有結合的に相 互に影響し合って三次構造の維持に関わっている(56-58)。そ のため、大変ユニークな糖鎖構造を有していると言う事がで きる。抗体糖鎖の微細な構造が ADCC 活性に及ぼす影響につ

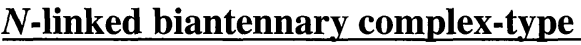

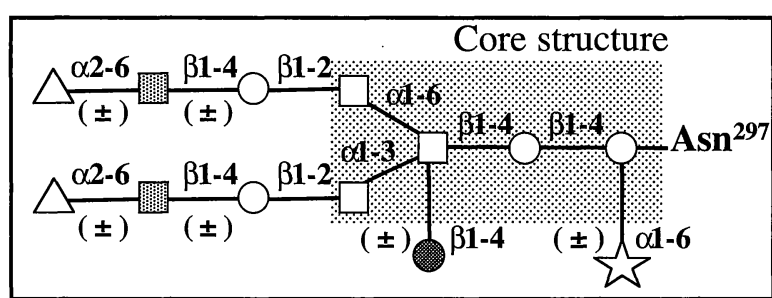

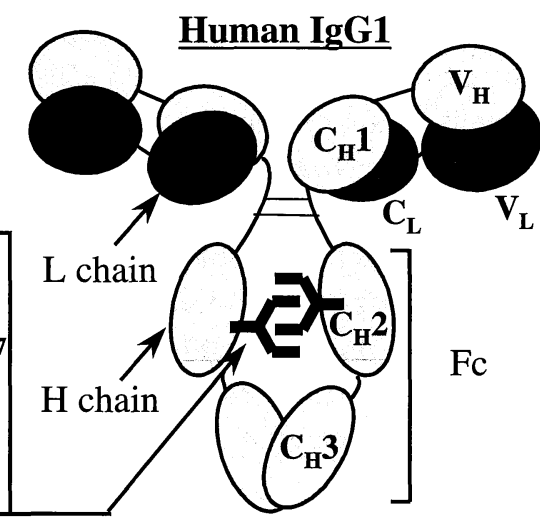

Fig. 2. Schematic drawing of human IgG1 oligosaccharide structure. The $N$-linked biantennary complex-type oligosaccharide is attached to the $\mathrm{C}_{\mathrm{H}} 2$ domain of the Fc region of human IgG1: GlcNAc ( $\bigcirc$ ), mannose ( $\square$ ), bisecting GlcNAc ( $\bigcirc)$, fucose $(\downarrow)$, galactose $(\square)$, sialic acid $(\Delta)$. 
been a matter of debate, research groups of Genentech and Kyowa Hakko Kogyo Co., Ltd. have found that the most important carbohydrate structure in terms of the enhancement of ADCC is the fucose attached to the innermost GlcNAc of the biantennary complex oligosaccharides $(10,11)$. The removal of fucose residues from the biantennary complex-type oligosaccharides attached to the $\mathrm{Fc}$ dramatically enhances the ADCC of the antibodies due to improved FcyRIIIa binding without altering either antigen binding or CDC activity (1019). Defucosylated antibodies achieve high effector activity at low doses, inducing high cellular cytotoxicity against tumor cells that express low levels of antigen (12), and triggering high effector function in NK cells with the low-affinity Fc $\gamma R$ IIIa allotype (FcyRIIIa-158Phe) for currently licensed therapeutic antibodies (13). The superior in vivo efficacy of defucosylated antibody has also been demonstrated using a human PBMC-engrafted mouse model (14). IgG bearing the Fc biantennary complex type of oligosaccharides lacking core fucosylation is a normal component of natural human serum $\mathrm{IgG}$, as mentioned above, and therefore there is little concern regarding its intrinsic immunogenicity. Thus, the application of defucosylated antibodies is expected to be among the most powerful and elegant approaches to the development of the next generation of therapeutic antibodies.

\section{F. Future Directions}

Recombinant protein expression technology in mammalian cell culture is the principal means of commercial production of therapeutic antibodies. Mammalian cells such as Chinese hamster ovary (CHO) cell lines or the mouse myeloma cell lines NS0 or SP2/0 have produced all therapeutic antibodies that are currently licensed on the market. However, these cell lines are not available for production of defucosylated therapeutic antibodies because they retain intrinsic $\alpha-1,6$-fucosyltransferase (FUT8) responsible for core fucosylation of the $\mathrm{Fc}$ oligosaccharide of the products. Thus, we have developed production methods of stably producing defucosylated therapeutic antibodies; FUT8-knockout cell lines have been established as ideal host cell lines to give stable yields of completely defucosylated therapeutic antibodies, irrespective of the production system (18), and small siRNAs against the FUT8 gene have been identified as convenient reagents capable of converting the established antibody-producing cells to more desired cell lines that produce highly defucosylated antibodies with improved ADCC (19). Clinical trials using defucosylated antibody therapeutics are currently in preparation.
いは長い間議論があったが、我々及び Genentech のグループ が、Fc 領域に結合する $N$-グリコシド結合複合型糖鎖還元末端 の $N$ - アセチルグルコサミンへのフコースの付加修飾こそが抗 体の ADCC 活性に最も大きな影響を与えることを明らかにし た $(10 、 11)$ 。抗体 Fc 領域に結合する $N$-グリコシド結合複合型 糖鎖還元末端の $N$ - アセチルグルコサミンからフコース残基を 除去すると Fc 受容体 IIIa に対する親和性が上がり ADCC 活性 が 100 倍以上と劇的に向上する(10-19)。この際、抗原結合活 性や CDC 活性には変化は観察されない。フコース非修飾抗体 は低い用量で高いエフェクター活性を示す能力を有しており、 癌抗原を低いレベルでしか発現していない癌細胞に対しても 高い殺細胞活性を示し (12)、現在認可されている既存の抗体 医薬に対して低い親和性しか示さない $\mathrm{Fc}$ 受容体アロタイプ

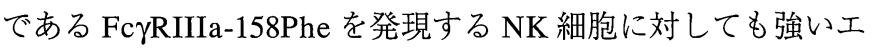
フェクター機能を惹起する (13)。フコース非修飾抗体の優れ たインビボの効果は、ヒト末梢血単核球を移植したマウスを 用いた腹水癌モデルにおいて示されている(14)。フコース修 飾のないコア構造を持つ $N$-グリコシド結合複合型糖鎖が付加 した IgGはヒトの血液中にも観察されており、その抗原性を 心配する必要はない。従って、フコース非修飾抗体を次世代 抗体医薬の開発に応用することは最もエレガントな方法の一 つとして期待されている。

\section{F. 今後の展開}

抗体医薬の商業生産は哺乳類細胞を用いた遺伝子組換え 法により行われている。現在上市されている抗体医薬の全て は、チャイニーズハムスター卵巣細胞由来の CHO 細胞株か、 あるいはマウス骨髄腫由来の NS0 あるいは SP2/0 細胞株を用 いて製造されている。しかしながら、これら細胞株は内在性 の $\alpha-1,6-$ フコース転移酵素を有しているため、生産した抗体 の糖鎖のコア構造にフコースが修飾されてしまう。そのため、 フコース非修飾抗体を製造する宿主細胞としては用いること ができない。そこで、我々は、安定にフコース非修飾抗体を 製造する方法を開発した。すなわち、製造方法に影響されず、 完全にフコース修飾のない抗体医薬を製造する理想的な宿主. 細胞として $\alpha-1,6-$ フコース転移酵素をノックアウトした細 胞株を樹立している(18)。また、既存の抗体医薬の生産株と いった既に樹立済みの抗体生産細胞を、高い ADCC 活性を有 する低フコース修飾抗体生産株一簡便に変換することが可能 な、 $\alpha-1,6-$ フコース転移酵素に対する RNA 干渉低分子も見出 した(19)。現在、フコース非修飾抗体医薬を用いた臨床試験 の準備が開始されている。

\section{References}

1. Forero, A., and Lobuglio, A.F. (2003) Semin. Oncol. 30, 1-5

2. Grillo-Lopez, A.J. (2003) Expert Rev. Anticancer Ther. 3, 767-769 
Trends in Glycoscience and Glycotechnology

3. Vogel, C.L., and Franco, S.X. (2003) Breast J. 9, 452-462

4. de Bono, J.S., and Rowinsky, E.K. (2002) Trends Mol. Med. 8, S19-S26

5. Cartron, G., Dacheux, L., Salles, G., Solal-Celigny, P., Bardos, P., Colombat, P., and Watier, H. (2002) Blood 99, 754-758

6. Dall'Ozzo, S., Tartas, S., Paintaud, G., Cartron, G., Colombat, P., Bardos, P., Watier, H., and Thibault, G. (2004) Cancer Res. 64, 46644669

7. Anolik, J.H., Campbell, D., Felgar, R.E., Young, F., Sanz, I., Rosenblatt, J., and Looney, R.J. (2003) Arthritis Rheum. 48, 455-459

8. Weng, W.K., and Levy, R. (2003) J. Clin. Oncol. 21, 3940-3947

9. Gennari, R., Menard, S., Fagnoni, F., Ponchio, L., Scelsi, M., Tagliabue, E., Castiglioni, F., Villani, L., Magalotti, C., Gibelli, N., Oliviero, B., Ballardini, B., Prada, G.D., Zambelli, A., and Costa, A. (2004) Clin. Cancer Res. 10, 5650-5655

10. Shields, R.L., Lai, J., Keck, R., O'Connell, L.Y., Hong, K., Meng, Y.G., Weikert, S.H., and Prest, L.G. (2002) J. Biol. Chem. 277, 2673326740

11. Shinkawa, T., Nakamura, K., Yamane, N., Shoji-Hosaka, E., Kanda, Y., Sakurada, M., Uchida, K., Anazawa, H., Satoh, M., Yamasaki, M., Hanai, N., and Shitara, K. (2003) J. Biol. Chem. 278, 3466-3473

12. Niwa, R., Sakurada, M., Kobayashi, Y., Uehara, A., Matsushima, K., Ueda, R., Nakamura, K., and Shitara, K. (2005) Clin. Cancer Res. 11, $2327-2336$

13. Niwa, R., Hatanaka, S., Shoji-Hosaka, E., Sakurada, M., Kobayashi, Y., Uehara, A., Yokoi, H., Nakamura, K., and Shitara, K. (2004) Clin. Cancer Res. 10, 6248-6255

14. Niwa, R., Shoji-Hosaka, E., Sakurada, M., Shinkawa, T., Uchida, K., Matsushima, K., Ueda, R., Hanai, N., and Shitara, K. (2004) Cancer Res. 64, 2127-2133

15. Okazaki, A., Shoji-Hosaka, E., Nakamura, K., Wakitani, M., Uchida, K., Kakita, S., Tsumoto, K., Kumagai, I., and Shitara, K. (2004) J. Mol .Biol. 336, 1239-1249

16. Niwa, R., Natsume, A., Uehara, A., Wakitani, M., Iida, S., Uchida, K., Satoh, M., and Shitara, K. (2005) J. Immunol. Methods 306, 151160

17. Natsume, A., Wakitani, M., Yamane-Ohnuki, N., Shoji-Hosaka, E., Niwa, R., Uchida, K., Satoh, M., and Shitara, K. (2005) J. Immunol. Methods 306, 93-103

18. Yamane-Ohnuki, N., Kinoshita, S., Inoue-Urakubo, M., Kusunoki, M., Iida, S., Nakano, R., Wakitani, M., Niwa, R., Sakurada, M., Uchida, K., Shitara, K., and Satoh, M. (2004) Biotechnol. Bioeng. 87, 614-622

19. Mori, K., Kuni-Kamochi, R., Yamane-Ohnuki, N., Wakitani, M., Yamano, K., Imai, H., Kanda, Y., Niwa, R., Iida, S., Uchida, K., Shitara, K., and Satoh, M. (2004) Biotechnol. Bioeng. 88, 901-908

20. Morrison, S.L., Johnson, M.J., Herzenberg, L.A., and Oi, V.T. (1984) Proc. Natl. Acad. Sci. USA. 81, 6851-6855

21. Boulianne, G.L., Hozumi, N., and Shulman, M.J. (1984) Nature 312, 643-646

22. Jones, P.T., Dear, P.H., Foote, J., Neuberger, M.S., and Winter, G. (1986) Nature 321, 522-525

23. Riechmann, L., Clark, M., Waldmann, H., and Winter, G. (1988) Nature 332, 323-327

24. Verhoeyen, M., Milstein, C., and Winter, G. (1988) Science 239, 1534-1536

25. Fishwild, D.M., O’Donnell, S.L., Bengoechea, T., Hudson, D.V., Harding, F., Bernhard, S.L., Jones, D., Kay, R.M., Higgins, K.M., Schramm, S.R., and Lonberg, N. (1996) Nat. Biotechnol. 14, 845-851

26. Mendez, M.J., Green, L.L., Corvalan, J.R.F., Jia, X.-C., Maynard-Currie, C.E., Yang, X.-D., Gallo, M.L., Loute, D.M., Lee, D.V., Erickson, K.L., Luna, J., Roy, C.M.-N., Abderrahim, H., Kirschenba, F., Noguchi, M., Smith, D.H., Fukushima, A., Hales, J.F., Finer, M.H., Davis, C.G., Zsebo, K.M., and Jakobovits, A. (1997) Nat. Genet. 15, 146-156

27. Tomizuka, K., Yoshida, H., Uejima, H., Kugoh, H., Sato, K., Ohguma, A., Hayasaka, M., Hanaoka, K., Oshimura, M., and Ishida, I. (1997) Nat. Genet. 16, 133-143

28. Tomizuka, K., Shinohara, T., Yoshida, H., Uejima, H., Ohguma, A., Tanaka, S., Sato, K., Oshimura, M., and Ishida, I. (2000) Proc. Natl. Acad. Sci. USA. 97, 722-727

29. Marks, J.D., Hoogenboom, H.R., Bonnert, T.P., McCafferty, J., Griffiths, A.D., and Winter, G. (1991) J. Mol. Biol. 222, 581-597

30. Marks, J.D., Ouwehand, W.H., Bye, J.M., Finnern, R., Gorick, B.D., Voak, D., Thorpe, S.J., Hughes-Jones, N.C., and Winter, G. (1993) Biotechnology (N Y) 11, 1145-1149

31. Griffin, H.M., and Ouwehand, W.H. (1995) Blood 86, 4430-4436

32. Reichert, J.M., Rosensweig, C.J., Faden, L.B., and Dewitz, M.C. (2005) Nat. Biotechnol. 23, 1073-1078

33. Alekshun, T., and Garrett, C. (2005) Cancer Control 12, 105-110

34. Whisenant, J., and Bergsland, E. (2005) Curr. Treat. Options Oncol. 6, 411-421

35. Adams, G.P., and Weiner, L.M. (2005) Nat. Biotechnol. 23, 1147-1157

36. Carter, P. (2001) Nat. Rev.Cancer 1, 118-129

37. Glennie, M.J., and van de Winkel, J.G.J. (2003) Drug Discov. Today 8, 503-510

38. Smith, M.R. (2003) Oncogene 22, 7359-7368

39. Shan, D., Ledbetter, J.A., and Press, O.W. (2000) Cancer Immunol. Immunother. 48, 673-683

40. Shields, R.L., Namenuk, A.K., Hong, K., Meng, Y.G., Rae, J., Briggs, J., Xie, D., Lai, J., Stadlen, A., Li, B., Fox, J.A., and Presta, L.G. (2001) J. Biol. Chem. 276, 6591-6604

41. Presta, L.G. (2002) Curr. Pharma. Biotechnol. 3, 237-256

42. Jefferis, R. (2005) Biotechnol. Prog. 21, 11-16

43. Clynes, R.A., Towers, T.L., Presta, L.G., and Ravetch, J.V. (2000) Nat. Med. 6, 443-446

44. van Ojik, H.H., Bevaart, L., Dahle, C.E., Bakker, A., Jansen, M.J., van Vugt, M.J., van de Winkel, J.G., and Weiner, G.J. (2003) Cancer Res. 63, 5595-5600

45. Jahrsdorfer, B., and Weiner, G.J. (2003) Semin. Oncol. 30, 476-482

46. Friedberg, J.W., Neuberg, D., Gribben, J.G., Fisher, D.C., Canning, C., Koval, M., Poor, C.M., Green, L.M., Daley, J., Soiffer, R., Ritz, J., and Freedman, A.S. (2002) Br. J. Haematol. 117, 828-834

47. Stockmeyer, B., Elsasser, D., Dechant, M., Repp, R., Gramatzki, M., Glennie, M.J., van de Winkel, J.G., and Valerius, T. (2001) J. Immunol. Methods 248, 103-111 
48. Shields, R.L., Namenuk, A.K., Hong, K., Meng, Y.G., Rae, J., Briggs, J., Xie, D., Lai, J., Stadlen, A., Li, B., Fox, J.A., and Presta, L.G. (2001) J. Biol. Chem. 276, 6591-6604

49. Presta, L.G. (2002) Curr. Pharma. Biotechnol. 3, 237-256

50. Jefferis, R. (2005) Biotechnol. Prog. 21, 11-16

51. Mizuochi, T., Taniguchi, T., Shimizu, A., and Kobata, A. (1982) J. Immunol. 129, 2016-2020

52. Harada, H., Kamei, M., Tokumoto, Y., Yui, S., Koyama, F., Kochibe, N., Endo, T., and Kobata, A. (1987) Anal. Biochem. 164, 374-381

53. Jefferis, R. (2002) BioPharm 14, 19-26

54. Kamoda, S., Nomura, C., Kinoshita, M., Nishiura, S., Ishikawa, R., Kakehi, K., Kawasaki, N., and Hayakawa, T. (2004) J. Chromatogr. A 1050, 211-216

55. Schenerman, M.A., Hope, J.N., Kletke, C., Singh, J.K., Kimura, R., Tsao, E.I., and Folena-Wasserman, G. (1999) Biologicals 27, 203-215

56. Huber, R., and Deisenhofer, J., and Colman, P.M. (1976) Nature 264, 415-420

57. Radaev, S., Motyka, S., Fridman, W., Sautes-Fridman, C., and Sun, P.D. (2001) J. Biol. Chem. 276, 16469-16477

58. Harris, L.J., Skaletsky, E., and McPherson, A. (1998) J. Mol. Biol. 275, 861-872

Received on December 18, 2005, accepted on February 14, 2006

Profile of the Authors

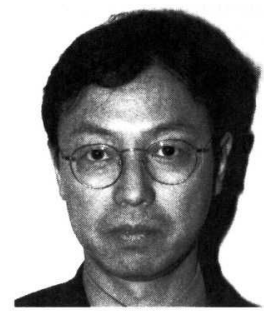

Mitsuo Satoh graduated from Master Course of Faculty of Pharmaceutical Science, Hokkaido University, and entered Kyowa Hakko Kogyo Co. Ltd., Japan in 1987 as a staff scientist of Tokyo Research Laboratories. He earned his Ph.D. from Hokkaido University in 1996. From 1996 to 1997 he worked for Institute of Bioscience and Technology, Texas Medical Center as a visiting scientist. He has been Senior Researcher of Tokyo Research Laboratories, Kyowa Hakko Kogyo Co. Ltd. since 1999. His major research fields are cellular engineering and antibody engineering. He received the first prize for encouragement from the Japanese Association for Animal Cell Technology in 2005, and received the 16th Kei Arima Memorial Award from the Japan Bioindustry Association in 2005.
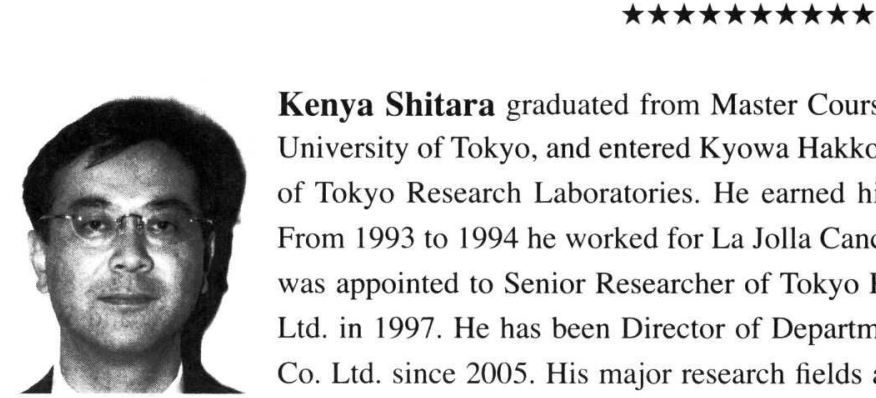

Kenya Shitara graduated from Master Course of Department of Pharmaceutical Science, The University of Tokyo, and entered Kyowa Hakko Kogyo Co. Ltd., Japan in 1984 as a staff scientist of Tokyo Research Laboratories. He earned his Ph.D. from The University of Tokyo in 1990. From 1993 to 1994 he worked for La Jolla Cancer Research Foundation as a visiting scientist. He was appointed to Senior Researcher of Tokyo Research Laboratories, Kyowa Hakko Kogyo Co. Ltd. in 1997. He has been Director of Department of Antibody Research, Kyowa Hakko Kogyo Co. Ltd. since 2005. His major research fields are tumor immunology and antibody engineering.

He received the 16th Kei Arima Memorial Award from the Japan Bioindustry Association in 2005.
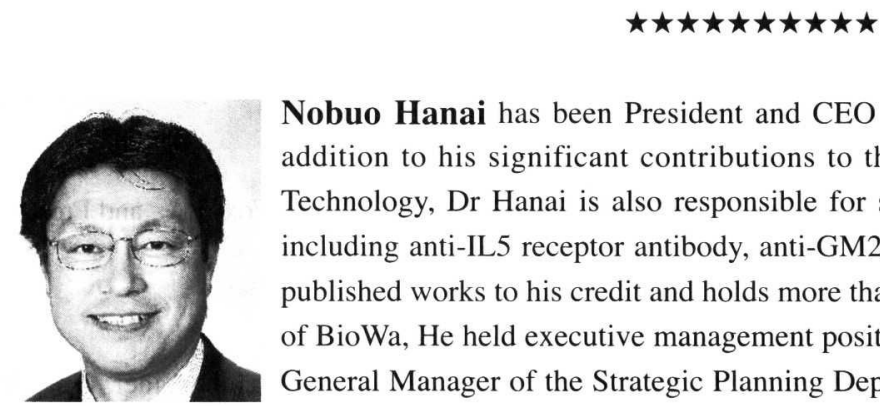

Nobuo Hanai has been President and CEO of BioWa, Inc. since its 2003 incorporation. In addition to his significant contributions to the discovery and development of Potelligent ${ }^{\mathrm{TM}}$ Technology, Dr Hanai is also responsible for science currently in BioWa's antibody pipelines, including anti-IL5 receptor antibody, anti-GM2 antibody and many others. He has more than 90 published works to his credit and holds more than 20 issued US patents. Prior to the establishment of BioWa, He held executive management positions with Kyowa Hakko Kogyo Co. Ltd., Japan General Manager of the Strategic Planning Department of its Pharmaceutical Company, Director of the Pharmaceutical Research Division of Tokyo Research Laboratories, and Associate Director of Tokyo Research Laboratories. 